\title{
スリットを有する天井放射パネルユニットの熱性能に関する研究 STUDY ON HEAT PERFORMANCE OF A CEILING SLIT PANEL UNIT FOR RADIANT COOLING AND HEATING
}

\author{
塩谷正樹*, 郡 公子**, 鬼頭 則夫*** \\ Masaki SHIOYA, Kimiko KOHRI and Norio KITO
}

\begin{abstract}
In the design of a ceiling radiant cooling and heating system, it is important to calculate the indoor thermal radiant environment and heat performance of a ceiling radiant panel. From the results of heat performance experiment, we clarified the radiative and convective heat transfer coefficient of a ceiling panel. And we developed the heat exchange equation model of a ceiling radiant panel using fin efficiency. The calculated values of the heat quantity using this model give close agreement with the actual measured values. Therefore, this model can be used to design ceiling radiant panels.
\end{abstract}

Keywords : Radiant cooling and heating system, Radiant panel, Radiative heat, Convective heat, Heat exchange equation 天井放射空調システム，放射パネル，放射熱，対流熱，熱交換式

\section{1.はじめに}

天井放射空調システムは，室内の放射環境を制御する熱的快適性 と，低エクセルギー熱利用による熱源システムの高効率運転や，地 中熱や太陽熱などの再生可能エネルギー直接利用，熱搬送効率の向 上など高い省エネルギー性を兼祇備えた空調システムとして，導入 事例が増加している1)-5)。放射パネルは室内の顕熱負荷を処理すると ともに，パネル表面温度によって快適性の高い放射環境とすること が可能であり，設計時において放射パネル熱量や室内の放射環境を 考慮しながら，放射パネルの配置や送水条件などを計画することが 重要である。石野 ${ }^{6)}$ は放射による効果を評価するために, 室内設計 条件を作用温度とし, 室内空気温度と表面温度を区別して, 熱負荷 や放射パネルの熱量を計算する手法を提案している。天井放射パネ ルの熱性能に関しては，代表的なパネル形状の表面熱伝達量や熱抵 抗の算出式7)があり，さらにこれまでに多くの実験が行われている。 瀬沼ら ${ }^{8)}$ は実験により対流, 放射熱伝達率を求め, 有限要素法によっ てパネル表面温度や熱量の検討を行っている。系井川ら ${ }^{9)}$ は実験に より冷却時の放射, 対流熱伝達率や, 送水往温度と室温の差を基準

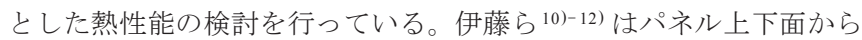
放熱する放射パネルについて，今川ら 13)14) は種々の放射パネルや配管 接続方式による熱性能の検討を行っている。しかし, これらの結果 は限定された実験条件下や放射パネル固有のものであり, 設計にお いては，任意の送水条件やパネル周囲の環境温度に応じた放射パネ 儿熱量が算出可能な実用的な熱交換式が必要である。熱交換式に関 して，岡本ら ${ }^{15)}$ や三村ら ${ }^{16)}$ は平板のパネルに配管を接続し，天井内 側を断熱した天井放射パネルをモデルとして熱交換式を導出してい
る。しかし, 熱量は室内空気温度と送水温度の差で評価するため, 放射パネルからみた平均放射温度 ( 以降 PRT) による影響は考慮され ていない。

本研究では，スリットを有することで，フィン付き配管独立構造 となる天井放射パネルを対象として, 設計手法を確立する上で必要 となる熱性能を実験により把握し, 任意の送水条件と, 放射パネル 周囲の空気温度と PRT の影響を考慮した環境温度から，放射パネル の熱量や表面温度の予測が可能な熱交換式を構築することを目的と する。

\section{2. 天井放射パネル熱性能実験の概要}

\section{1 天井放射パネル}

図 1 に対象となる天井放射パネルを示す。放射パネルは 1 ユニッ

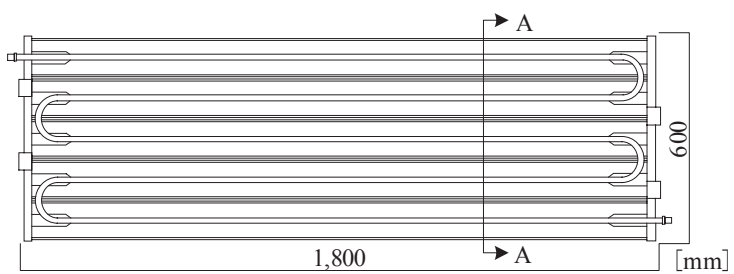

(a) 平面図

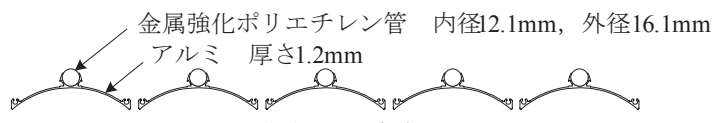

(b) $\mathrm{A}-\mathrm{A}$ 矢視図

図 1 天井放射パネル

\footnotetext{
* 三建設備工業(跦技術本部技術研究所 修士 (工学)

** 宇都宮大学大学院工学研究科 准教授.工博

*** 三建設備工業侏技術本部技術研究所
}

Research Engineer, Sanken Setsubi Kogyo Co., Ltd., M. Eng.

Assoc. Prof., Graduate School of Engineering, Utsunomiya Univ., Dr. Eng. Research Engineer, Sanken Setsubi Kogyo Co., Ltd. 
トあたりが $600 \times 1,800$ のアルミ製で，各パネル部の断面は曲面形状 となっており，パネル上下面から放熱する。また，放射パネル間に はスリットが設けられ，室内と天井内の間で空気が流動する。

\section{2 実験概要}

図 2 に実験室, 表 1 , 表 2 に実験条件と測定項目を示す。実験室は
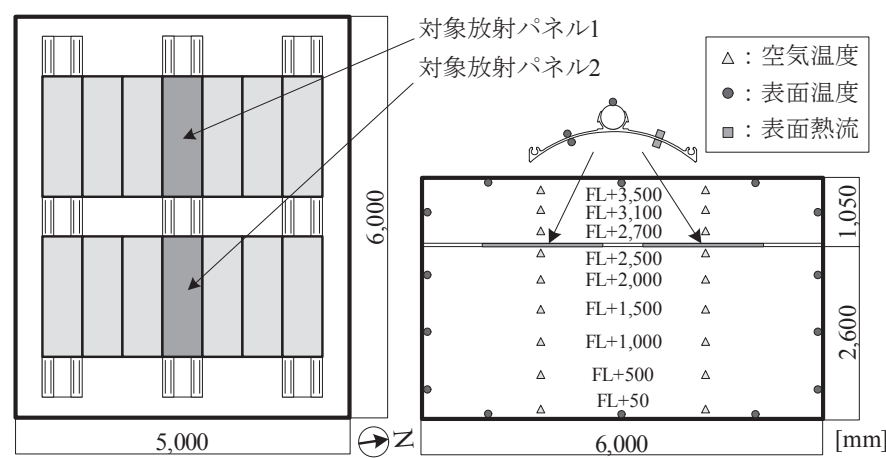

図 2 実験室平面図と断面図

表 1 実験条件

\begin{tabular}{|c|c|c|}
\hline \multirow{2}{*}{\multicolumn{2}{|c|}{$\begin{array}{l}\text { 実験対象 } \\
\text { 実験年月 }\end{array}$}} & 室中央放射パネル $600 \times 1,800 \times 2$ 枚 \\
\hline & & 暖房 $2011 / 12 \sim 2012 / 2$ \\
\hline \multirow{2}{*}{$\begin{array}{c}\text { 冷房 } \\
\text { 送水条件 }\end{array}$} & 温度 $\left[{ }^{\circ} \mathrm{C}\right]$ & $16,17,18,19,20,21,22,23,24$ \\
\hline & 流量 [L/min] & $1,2,3,4,5,6,7,8,9,10$ \\
\hline \multirow{2}{*}{$\begin{array}{c}\text { 暖房 } \\
\text { 送水条件 }\end{array}$} & 温度 $\left[{ }^{\circ} \mathrm{C}\right]$ & $18,20,22.5,25,27.5,30,32.5,35,37.5,40$ \\
\hline & 流量 [L/min] & $0.5,1,1.5,2,3,4,5,6,7,8,10$ \\
\hline
\end{tabular}

表 2 測定項目

\begin{tabular}{|c|c|c|}
\hline 測定項目 & 測定機器 & 測定点 \\
\hline 送水温度 & 測温抵抗体 Pt100 & 各放射パネル往還：4点 \\
\hline 送水流量 & 電磁流量計 & 各放射パネル：2点 \\
\hline 空気温度 & サーミスタ温度計 & 室内: 12点, 天井内 : 6点 \\
\hline 表面温度 & $\begin{array}{l}\mathrm{T} \text { 型熱電対 } \\
\text { 赤外線サーモ } \\
\text { グラフィ }\end{array}$ & $\begin{array}{l}\text { 室内壁 : } 20 \text { 点, 床 : 9点, 対象放射パネル : } 14 \text { 点 } \\
\text { 天井板, 非対象放射パネル : 14点 } \\
\text { 天井内壁 : } 12 \text { 点, 天井スラブ : 9点 } \\
\text { 天井内梁, ダクト : 3点 }\end{array}$ \\
\hline 表面熱流 & 熱流計 & $\begin{array}{l}\text { 室内壁 : } 6 \text { 点, 床 : } 1 \text { 点, 対象放射パネル }: 4 \text { 点 } \\
\text { 天井板 : } 1 \text { 点, 天井内壁 : 4点, 天井スラブ : } 1 \text { 点 }\end{array}$ \\
\hline
\end{tabular}

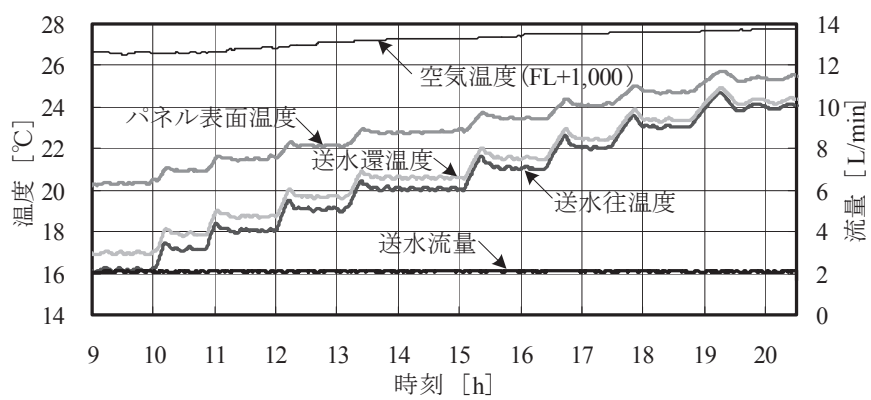

図 3 冷房時における時刻変動 $(2 \mathrm{~L} / \mathrm{min}$ 時)

表 3 熱伝達率の算出に関する式

\begin{tabular}{|c|}
\hline 放射パネル熱量 [W] \\
\hline $\begin{array}{c}\quad q_{p}=C_{p} \rho Q\left|t_{w i}-t_{w o}\right| \\
\text { 放射パネル放射熱伝達量 }[\mathrm{W}]\end{array}$ \\
\hline$q_{r}=\sigma A_{i} \varepsilon_{i} \sum g_{i j}\left|T_{i}^{4}-T_{j}^{4}\right|$ \\
\hline 放射パネルからみた平均放射温度 (PRT) [K] \\
\hline$P R T=\sqrt[4]{\sum g_{i j} T_{j}^{4}}$ \\
\hline 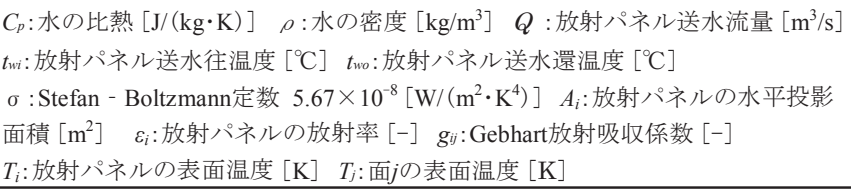 \\
\hline
\end{tabular}

$5,000 \times 6,000$ で，14 枚の天井放射パネルを設置している。本実験では 室中央部の放射パネル 2 枚に, 表 1 に示寸送水温度と送水流量を組 み合わせて測定する。解析に用いた条件は冷房時 82 ケース, 暖房時 106 ケースである。測定は, 送水温度と流量, 空気温度, 表面温度, 表面熱流を 30 秒間隔で行う。さらに, 赤外線サーモグラフィにより 放射パネル直下からパネル表面温度分布を測定する。なお，実験中 の熱供給は放射パネルのみとし, 室内温度は成り行きとする。また, 暖房時は送水温度と室内環境温度の差が小さい条件を測定するため に, 送水温度下限を $18^{\circ} \mathrm{C}$ 程度とする。測定例として, 図 3 に冷房時 における時刻変動を示す。

\section{3. 天井放射パネルの放射, 対流熱伝達率}

実験結果より，放射パネル表面の放射熱伝達率と対流熱伝達率を 算出する。表 3 に熱伝達率算出に用いた式を示す。放射パネル熱量 を式(1)より求め, パネル上下面の熱流計測定值の割合から室内側, 天井内側への熱量に分ける。室内側, 天井内側への放射熱伝達量は 式(2)より求める。Gebhart 放射吸収係数 ${ }^{17)}$ は, 室内形状や天井内ダク トをモデル化し，モンテカルロ法により求める。図 4 に天井内側の モデルを示す。なお，放射率は天井スラブ，ダクト表面を 0.6 , その 他の表面を 0.9 として計算する。表 4 に対象放射パネルにおける Gebhart 放射吸收係数を示す。対流熱伝達量は室内側，天井内側への 熱量と放射熱伝達量の差によって求める。また, 各表面熱伝達率を

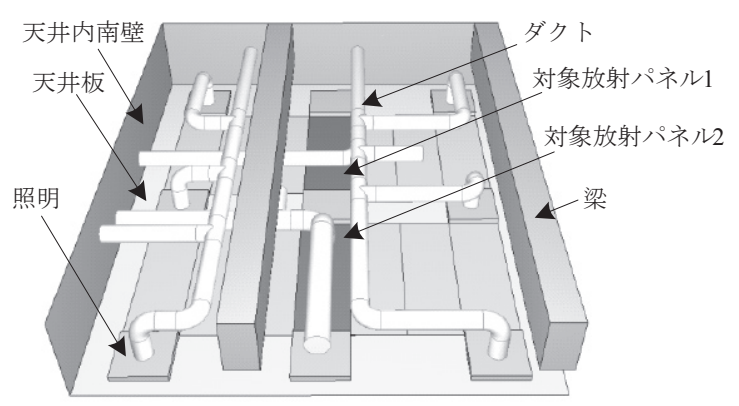

図 4 天井内側モデル

表 4 対象放射パネルにおける Gebhart 放射吸収係数 (a) 放射パネル 1 天井内側

\begin{tabular}{|c|c|}
\hline 部位 & $g_{i j}$ \\
\hline 天井スラブ & 0.29 \\
\hline 梁 & 0.16 \\
\hline 天井内東壁 & 0.00 \\
\hline 天井内南壁 & 0.01 \\
\hline 天井内西壁 & 0.06 \\
\hline 天井内北壁 & 0.01 \\
\hline 非対象放射パネル & 0.09 \\
\hline 対象放射パネル & 0.06 \\
\hline ダクト & 0.24 \\
\hline 天井板・照明 & 0.08 \\
\hline \multicolumn{2}{|l|}{ (c) 放射パネル 1} \\
\hline 部位 & $g_{i j}$ \\
\hline 床 & 0.48 \\
\hline 東壁 & 0.03 \\
\hline 東空 & 0.02 \\
\hline 南壁 & 0.12 \\
\hline 西壁 & 0.14 \\
\hline 西空 & 0.05 \\
\hline 北壁 & 0.12 \\
\hline 非対象放射パネル & 0.02 \\
\hline 天井板・照明 & 0.02 \\
\hline
\end{tabular}

(b) 放射パネル 2 天井内側

\begin{tabular}{l|l}
\hline \multicolumn{1}{c|}{ 部位 } & $\mathrm{g}_{\mathrm{ij}}$ \\
\hline 天井スラブ & 0.21 \\
\hline 梁 & 0.15 \\
\hline 天井内東壁 & 0.05 \\
\hline 天井内南壁 & 0.02 \\
\hline 天井内西壁 & 0.00 \\
\hline 天井内北壁 & 0.01 \\
\hline 非対象放射パネル & 0.09 \\
\hline 対象放射パネル & 0.06 \\
\hline ダクト & 0.33 \\
\hline 天井板・照明 & 0.08 \\
\hline
\end{tabular}

\begin{tabular}{l|c}
\hline (d) 放射パネル 2 & 室内側 \\
\hline \multicolumn{1}{c|}{ 部位 } & $\mathrm{g}_{\mathrm{ij}}$ \\
\hline 床 & 0.47 \\
\hline 東壁 & 0.11 \\
\hline 東空 & 0.09 \\
\hline 南壁 & 0.12 \\
\hline 西壁 & 0.04 \\
\hline 西空 & 0.01 \\
\hline 北壁 & 0.12 \\
\hline 非対象放射パネル & 0.02 \\
\hline 天井板・照明 & 0.02 \\
\hline
\end{tabular}


求める際, PRT は式 (3) より求め, 室内空気温度は FL $+2,000$ 以下の平 均值を用い, 天井内空気温度は $\mathrm{FL}+3,100$ 以上の平均值を用いて, 放 射パネル表面温度との差を求める。

図 5, 6 に冷房時における天井内側, 室内側一の放射, 対流熱伝達
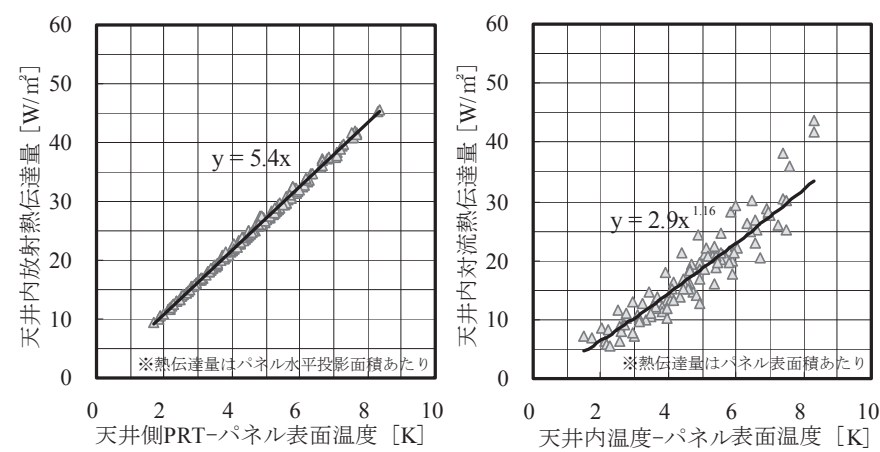

図 5 冷房時天井内側放射・対流熱伝達量
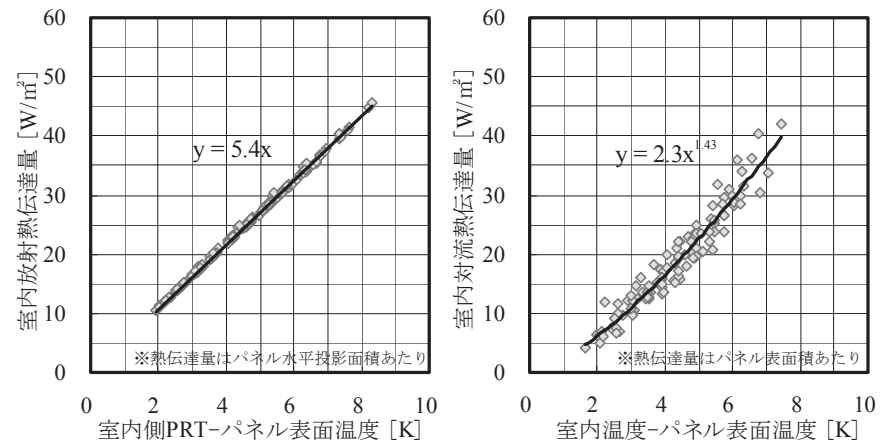

図 6 冷房時室内側放射・対流熱伝達量
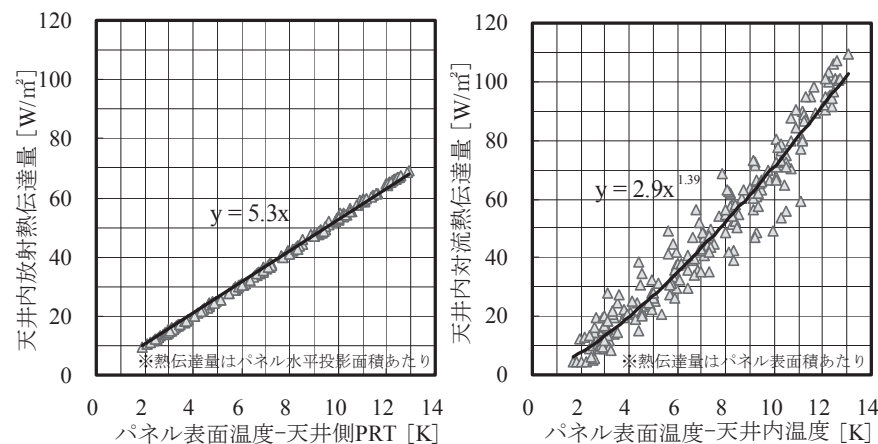

図 7 暖房時天井内側放射 - 対流熱伝達量
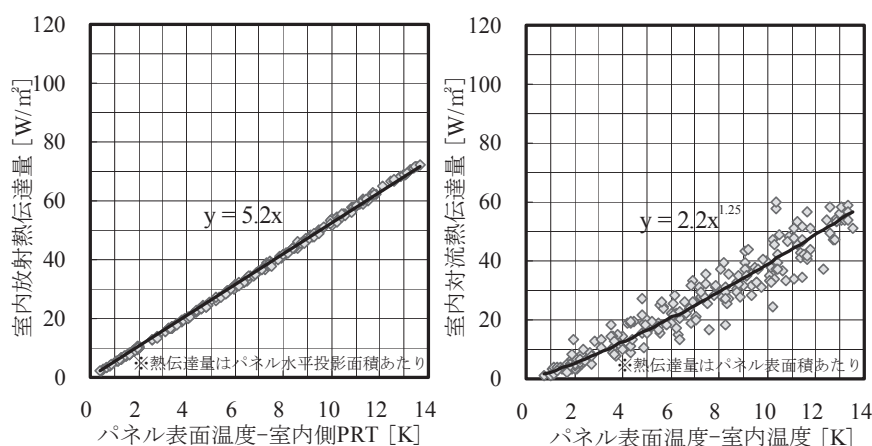

図 8 暖房時室内側放射・対流熱伝達量

表 5 放射パネル表面熱伝達率

\begin{tabular}{c|c|c|c}
\hline \multicolumn{2}{c|}{} & 放射熱伝達率 $\left[\mathrm{W} / \mathrm{m}^{2} \mathrm{~K}\right]$ & 対流熱伝達率 $\left[\mathrm{W} / \mathrm{m}^{2} \mathrm{~K}\right]$ \\
\hline \multirow{2}{*}{ 冷房 } & 天井内側 & 5.4 & $2.9\left|\mathrm{t}_{\mathrm{p}}-\mathrm{t}_{\mathrm{a}}\right|^{0.16}$ \\
\cline { 2 - 4 } & 室内側 & 5.4 & $2.3\left|\mathrm{t}_{\mathrm{p}}-\mathrm{t}_{\mathrm{a}}\right|^{0.43}$ \\
\hline \multirow{2}{*}{ 暖房 } & 天井内側 & 5.3 & $2.9\left|\mathrm{t}_{\mathrm{p}}-\mathrm{t}_{\mathrm{a}}\right|^{0.39}$ \\
\cline { 2 - 4 } & 室内側 & 5.2 & $2.2\left|\mathrm{t}_{\mathrm{p}}-\mathrm{t}_{\mathrm{a}}\right|^{0.25}$ \\
\hline \multicolumn{2}{|c|}{ ※ $\mathrm{t}_{\mathrm{p}}$ はパネル表面温度, $\mathrm{t}_{\mathrm{a}}$ は空気温度を示す }
\end{tabular}

量を示す。各温度差と熱伝達量は高い相関がみられる。放射熱伝達 量は温度差が大きくなるにつれてほぼ一定の割合で増加する。対流 熱伝達量は温度差が大きくなるにつれて増加する割合が大きくなり， 温度差あたりの熱伝達量は室内側の方が大きい傾向がみられる。

図 7, 8 に暖房時における天井内側, 室内側一の放射, 対流熱伝達 量を示す。暖房時においても各温度差と熱伝達量は高い相関がみら れ, 放射熱伝達量は温度差が大きくなるにつれて, 一定の割合で増 加し, 対流熱伝達量は温度差が大きくなるにつれて, 増加する割合 が大きくなる傾向がみられる。温度差あたりの対流熱伝達量は天井 内側の方が大きい。これらの結果の近似式の傾きより, 表 5 に示す 各表面熱伝達率が得られる。

\section{4. 天井放射パネルの熱交換モデル}

対象とした天井放射パネルの熱量を実用的な計算式から推定する ために, 放射パネルの熱量をフィン効率 ${ }^{18)}$ を用いてモデル化し, 放 射パネルの熱貫流率を導く。図 9 に天井放射パネルのモデルと記号 を示す。なお，熱貫流率を導くにあたり，放射パネルの配管を放熱 性能が等価で, 外表面温度 $t_{p o}$ の仮想配管に置き換える。

\section{1 配管内部の熱伝達量}

配管内部の熱伝達は配管のみの部位と，配管とパネルが接続され ている部位の熱伝導の違いを考慮する。

配管内の水から配管外表面への熱伝達量は式(4)である。

$$
q_{p}=\left(K_{p 1} A_{m l}+K_{p 2} A_{m 2}\right) \cdot\left(t_{w}-t_{p o}\right)
$$

ここに, $K_{p l}, A_{m I}$ は, 配管の夕の部位の熱伝達率 $\left[\mathrm{W} / \mathrm{m}^{2} \mathrm{~K}\right]$ と平均 熱伝達面積 $\left[\mathrm{m}^{2}\right], K_{p 2}, A_{m 2}$ は, 配管とパネルが接続されている部位

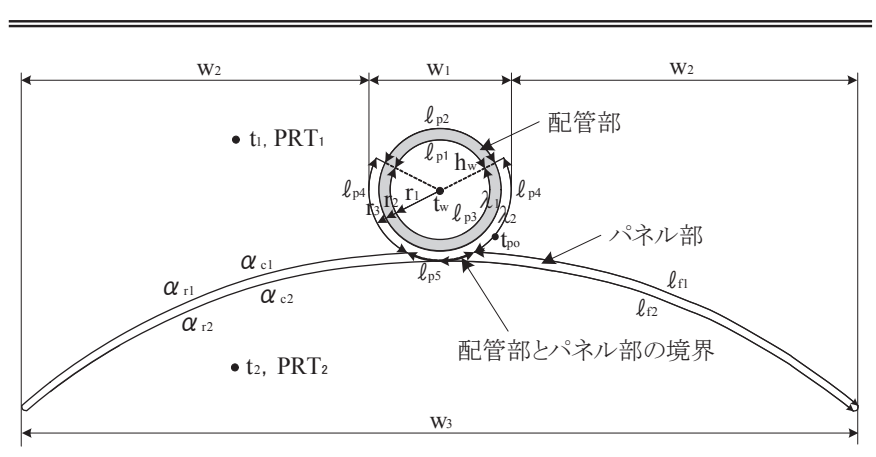

$q_{p}$ : パネル熱伝達量 $[\mathrm{W}] \quad h_{w}$ : 配管内熱伝達率 $\left[\mathrm{W} / \mathrm{m}^{2} \mathrm{~K}\right] \quad R$ : 配管一パネル間 接触抵抗 $\left[\mathrm{m}^{2} \mathrm{~K} / \mathrm{W}\right] \quad \lambda_{1}$ :配管熱伝導率 $[\mathrm{W} / \mathrm{mK}] \quad \lambda_{2}$ : パネル熱伝導率 $[\mathrm{W} / \mathrm{mK}]$ $\alpha_{r l}$ : 天井内側放射熱伝達率 $\left[\mathrm{W} / \mathrm{m}^{2} \mathrm{~K}\right] \quad \alpha_{r 2}$ : 室内側放射熱伝達率 $\left[\mathrm{W} / \mathrm{m}^{2} \mathrm{~K}\right]$ $\alpha_{c 1}$ : 天井内側対流熱伝達率 $\left[\mathrm{W} / \mathrm{m}^{2} \mathrm{~K}\right] \quad \alpha_{c 2}$ : 室内側対流熱伝達率 $\left[\mathrm{W} / \mathrm{m}^{2} \mathrm{~K}\right]$ $v$ :配管内流速 $[\mathrm{m} / \mathrm{s}] \quad \eta:$ パネルフィン効率 $[-]$

$r_{1}$ : 配管内半径 $[\mathrm{m}] \quad r_{2}$ : 配管外半径 $[\mathrm{m}] \quad r_{3}$ : 配管中心からパネル表面までの 距離 $[\mathrm{m}] \quad \ell_{\mathrm{pl}}$ : 配管内面弧長さ (パネル未接触部) $[\mathrm{m}] \quad \ell_{\mathrm{p}}$ : 配管外面弧長さ(パ ネル未接触部) $[\mathrm{m}] \quad \ell_{\mathrm{p} 3}$ ：配管内面弧長さ(パネル接触部) $[\mathrm{m}] \quad \ell_{\mathrm{p} 4}$ ：配管外面 弧長さ(パネル接触部) $[\mathrm{m}] \quad \ell_{\mathrm{p}}$ : 配管一パネル接触部の弧長さ $[\mathrm{m}] \quad \ell_{\mathrm{fl}}$ : 天井 内側配管部からパネル先端までの長さ $[\mathrm{m}] \quad \ell_{\mathrm{n}}$ : 室内側配管部からパネル先端 までの長さ $[\mathrm{m}] \mathrm{w}_{1}$ : 配管部の水平幅 $[\mathrm{m}] \mathrm{w}_{2}$ : パネル部の水平幅 $[\mathrm{m}]$ $\mathrm{w}_{3}$ : パネルの水平幅 $[\mathrm{m}] L$ : 送水方向長さ $[\mathrm{m}] t_{w}$ : 水の温度 $\left[{ }^{\circ} \mathrm{C}\right] t_{p o}$ : 配管 外表面温度 $\left[{ }^{\circ} \mathrm{C}\right] t_{1}$ : 天井内空気温度 $\left[{ }^{\circ} \mathrm{C}\right] \quad P R T_{1}$ : パネルからみた天井内平均 放射温度 $\left[{ }^{\circ} \mathrm{C}\right] t_{2}$ : 室内空気温度 $\left[{ }^{\circ} \mathrm{C}\right] \quad P R T_{2}$ : パネルからみた室内平均放射温 度 $\left[{ }^{\circ} \mathrm{C}\right]$ te : パネル環境温度 $\left[{ }^{\circ} \mathrm{C}\right]$

図 9 天井放射パネルモデルと記号 
の熱伝達率 $\left[\mathrm{W} / \mathrm{m}^{2} \mathrm{~K}\right]$ と平均熱伝達面積 $\left[\mathrm{m}^{2}\right]$ であり, 式 $(5) \sim(8)$ で表 せる。

$$
\begin{aligned}
& K_{p l}=\frac{1}{\frac{1}{h_{w}}+\frac{r_{2}-r_{1}}{\lambda_{1}}} \\
& A_{m l}=\frac{\left(\ell_{p 2}-\ell_{p l}\right) L}{\ln \left(\ell_{p 2} / \ell_{p l}\right)} \\
& K_{p 2}=\frac{1}{\frac{1}{h_{w}}+\frac{r_{2}-r_{1}}{\lambda_{1}}+\frac{r_{3}-r_{2}}{\lambda 2}+R} \\
& A_{m 2}=\frac{\left(2 \ell_{p 4}+\ell_{p 5}-\ell_{p 3} 3\right) L}{\ln \left\{\left(2 \ell_{p 4}+\ell_{p 5}\right) / \ell_{p 3}\right\}} \\
& h_{w}=\left(1663+24 t_{w}\right) v^{0.8} /\left(2 r_{1}\right)^{0.2} \\
& \text { よって, 式 }(4) \text { は式 }(10) \text { で表せる。 } \\
& q_{p}=\left[K_{p 1} \frac{\ell_{p 2}-\ell_{p l}}{\ln \left(\ell_{p 2} / \ell_{p 1}\right)}+K_{p 2} \frac{2 \ell_{p 4}+\ell_{p 5}-\ell_{p 3}}{\ln \left\{\left(2 \ell_{p 4}+\ell_{p 5}\right) / \ell_{p 3}\right\}}\right] L\left(t_{w}-t_{p o}\right)
\end{aligned}
$$

\section{2 配管・放射パネル表面と周囲環境間の熱伝達量}

配管, パネル表面と周囲環境間の熱伝達式を導くにあたり，放射 熱伝達に有効な面積は水平投影面積として近似する。

配管部の外表面と周囲環境間の熱伝達量 $q_{p p}$ は式 (11) である。

$q_{p p}=\alpha_{r I} w_{1} L\left(t_{p o p}-P R T_{1}\right)+\alpha_{c 1}\left(l_{p 2}+2 \ell_{p 4}\right) L\left(t_{p o p}-t_{1}\right)$

$$
t_{p o p} \text { : 配管部の外表面温度 }
$$

ここで,

$h_{p}=\alpha_{r 1}+\frac{\ell_{p 2}+2 \ell_{p 4}}{w_{1}} \alpha_{c 1}$

$t_{p}=\frac{\alpha_{r 1} P R T_{1}+\frac{\ell_{p 2}+2 \ell_{p 4}}{w_{1}} \alpha_{c 1 t_{1}}}{h_{p}}$

とすると, 式(14) となる。

$q_{p p}=h_{p} w I L\left(t_{p o p}-t e_{p}\right)$

天井内側パネル部表面と周囲環境間の熱伝達量 $q_{p f}$ は, フィン効率 を用いると式(15) で表せる。

$\begin{aligned} q_{p f}= & \alpha_{r l} 2 w_{2} L \eta\left(t_{p o f}-P R T_{1}\right)+\alpha_{c 12} \ell_{f 1} L \eta\left(t_{p o f}-t_{1}\right) \\ & t_{p o f}: \text { パネル根元温度 }\end{aligned}$

$$
\text { ここで, }
$$

$h_{f}=\alpha_{r 1}+\left(\ell_{f 1} / w_{2}\right) \alpha_{c l}$

$t_{f}=\frac{\alpha_{r 1} P R T_{1}+\left(l_{f 1} / w_{2}\right) \alpha_{c l t}}{h_{f}}$

とすると, 式(18) となる。

$q_{p f}=h_{f} 2 w_{2} L \eta\left(t_{p o f}-t_{f}\right)$

式(14)，(18)より，天井内側放射パネルと周囲環境間の熱伝達量 $q_{p l}$ は式(19)である。

$$
\begin{aligned}
& q_{p l}=q_{p p}+q_{p f} \\
&=h_{p} w_{1} L\left(t_{p o p}-t e_{p}\right)+h_{f} 2 w_{2} L \eta\left(t_{p o f}-t e_{f}\right) \\
& \text { ここで, } \\
& h_{1}=\left(w_{1} / w_{3}\right) h_{p}+\left(2 w_{2} / w_{3}\right) \eta h_{f} \\
& t_{p o l}=\frac{\left(w_{1} / w_{3}\right) h_{p} t_{p o p}+\left(2 w_{2} / w_{3}\right) \eta h_{f} t_{p o f}}{h_{1}} \\
& t e_{1}=\frac{\left(w_{1} / w_{3}\right) h_{p} t e_{p}+\left(2 w_{2} / w_{3}\right) \eta h_{f} t e_{f}}{h_{1}}
\end{aligned}
$$

とすると, 式(23) となる。

$q_{p l}=h_{1} w_{3} L\left(t_{p o l}-t e l\right)$

一方, 室内側放射パネルと周囲環境間の熱伝達量 $q_{p 2}$ は式 (24) で表 せる。

$$
q_{p 2}=\alpha_{r 2} w_{3} L \eta\left(t_{p o f}-P R T_{2}\right)+\alpha_{c 2} 2 l_{f 2 L} \eta\left(t_{p o f}-t_{2}\right)
$$

ここで,

$h_{2}=\alpha_{r_{2}}+\left(2 \ell_{52} / w_{3}\right) \alpha_{c 2}$

$t e_{2}=\frac{\alpha_{r_{2}} P R T_{2}+\left(2 \ell_{f 2} / w_{3}\right) \alpha_{c 2} t_{2}}{h_{2}}$

とすると, 式(27) となる。

$q_{p 2}=h_{2} w_{3} L \eta\left(t_{p o f}-t e_{2}\right)$

よって, 放射パネル表面とパネル周囲環境間の熱伝達量 $q_{p}$ は, 式 (23)，(27)より，式(28)で表せる。

$$
\begin{aligned}
& q_{p}=q_{p 1}+q_{p 2} \\
&=h_{1} w_{3} L\left(t_{p o l}-t e_{1}\right)+h_{2} w_{3} L \eta\left(t_{p o f}-t e_{2}\right) \\
& \text { ここで, } \\
& h=h_{1}+\eta h_{2} \\
& t_{p o}=\frac{h_{1} t_{p o l}+\eta h_{2} t_{p o f}}{h} \\
& t e=\frac{h_{1} t e_{1}+\eta h_{2} t e_{2}}{h}
\end{aligned}
$$

\begin{tabular}{|c|c|c|c|c|}
\hline $\mathrm{r}_{1}[\mathrm{~m}]$ & 0.006 & $\ell_{\mathrm{f} 1}$ & {$[\mathrm{~m}]$} & 0.054 \\
\hline $\mathrm{r}_{2}[\mathrm{~m}]$ & 0.008 & $l_{12}$ & {$[\mathrm{~m}]$} & 0.058 \\
\hline $\mathrm{r}_{3}[\mathrm{~m}]$ & 0.010 & $\lambda_{1}[$ & $\mathrm{W} / \mathrm{mK}]$ & 0.47 \\
\hline$\ell_{\mathrm{pl} 1}[\mathrm{~m}]$ & 0.014 & $\lambda_{2}[$ & $\mathrm{W} / \mathrm{mK}]$ & 210 \\
\hline$\ell_{\mathrm{p} 2}[\mathrm{~m}]$ & 0.018 & \multirow{4}{*}{ 冷房 } & $\alpha_{\mathrm{r} 1}\left[\mathrm{~W} / \mathrm{m}^{2} \mathrm{~K}\right]$ & 5.4 \\
\hline$\ell_{\mathrm{p} 3}[\mathrm{~m}]$ & 0.024 & & $\alpha_{\mathrm{cl} 1}\left[\mathrm{~W} / \mathrm{m}^{2} \mathrm{~K}\right]$ & $2.9\left|\mathrm{t}_{\mathrm{p}}-\mathrm{ta}_{\mathrm{a}}\right|^{0.16}$ \\
\hline$\ell_{\mathrm{p}^{4}}[\mathrm{~m}]$ & 0.013 & & $\alpha_{\mathrm{r} 2}\left[\mathrm{~W} / \mathrm{m}^{2} \mathrm{~K}\right]$ & 5.4 \\
\hline$\ell_{\mathrm{p} 5}[\mathrm{~m}]$ & 0.012 & & $\alpha_{c 2}\left[\mathrm{~W} / \mathrm{m}^{2} \mathrm{~K}\right]$ & $2.3\left|\mathrm{t}_{\mathrm{p}}-\mathrm{t}_{\mathrm{a}}\right|^{0.43}$ \\
\hline $\mathrm{w}_{1}[\mathrm{~m}]$ & 0.019 & \multirow{4}{*}{ 暖房 } & $\alpha_{\mathrm{r} 1}\left[\mathrm{~W} / \mathrm{m}^{2} \mathrm{~K}\right]$ & 5.3 \\
\hline $\mathrm{W}_{2}[\mathrm{~m}]$ & 0.044 & & $\alpha_{\mathrm{cl}}\left[\mathrm{W} / \mathrm{m}^{2} \mathrm{~K}\right]$ & $2.9\left|\mathrm{t}_{\mathrm{p}}-\mathrm{t}_{\mathrm{a}}\right|^{0.39}$ \\
\hline $\mathrm{W}_{3}[\mathrm{~m}]$ & 0.108 & & $\alpha_{\mathrm{r} 2}\left[\mathrm{~W} / \mathrm{m}^{2} \mathrm{~K}\right]$ & 5.2 \\
\hline $\mathrm{L}[\mathrm{m}]$ & 8.9 & & $\alpha_{\mathrm{c} 2}\left[\mathrm{~W} / \mathrm{m}^{2} \mathrm{~K}\right]$ & $2.2\left|\mathrm{t}_{\mathrm{p}}-\mathrm{t}_{\mathrm{a}}\right|^{0.25}$ \\
\hline
\end{tabular}

\begin{tabular}{|c|c|c|c|}
\hline & 冷房/暖房 & 接触抵抗 $\mathrm{R}\left[\mathrm{m}^{2} \mathrm{~K} / \mathrm{W}\right]$ & フィン効率 $\eta[-]$ \\
\hline CASE1-1 & \multirow{6}{*}{ 冷房 } & \multirow{3}{*}{0.001} & 0.60 \\
\hline CASE1-2 & & & 0.70 \\
\hline CASE1-3 & & & 0.79 \\
\hline CASE1-4 & & \multirow{3}{*}{0.01} & 0.70 \\
\hline CASE1-5 & & & 0.79 \\
\hline CASE1-6 & & & 0.90 \\
\hline CASE2-1 & \multirow{6}{*}{ 暖房 } & \multirow{3}{*}{0.001} & 0.55 \\
\hline CASE2-2 & & & 0.65 \\
\hline CASE2-3 & & & 0.79 \\
\hline CASE2-4 & & \multirow{3}{*}{0.01} & 0.65 \\
\hline CASE2-5 & & & 0.79 \\
\hline CASE2-6 & & & 0.90 \\
\hline
\end{tabular}

とすると, 式(32)となる。

$q_{p}=h w_{3} L\left(t_{p o}-t e\right)$

\section{3 放射パネルの熱伝達量}

式(10)，(32)を整理すると，放射パネルの熱伝達量は式(33)で表 せる。

$$
\begin{aligned}
& q_{p}=K L\left(t_{w}-t e\right) \\
& \text { ここに, }
\end{aligned}
$$

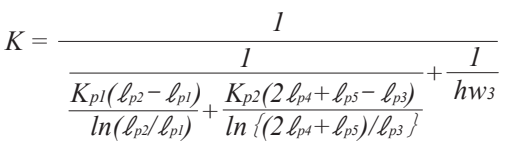

式 (33) において, 送水温度と環境温度の差は対数平均温度差であ り, 式(35)で表せる。

$$
t_{w}-t e=\frac{t_{w i}-t_{w o}}{\ln \left\{\left(t_{w i}-t e\right) /\left(t_{w o}-t e\right)\right\}}
$$

式 (33) が放射パネルの熱交換式であり，放射パネルへの送水温度

表 6 放熱量の計算条件

表 7 計算ケース 


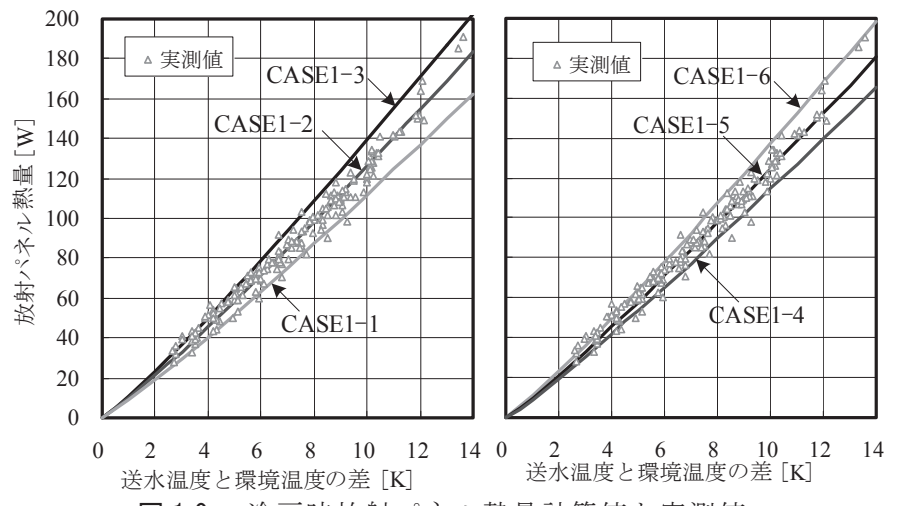

図 10 冷房時放射パネル熱量計算值と実測值
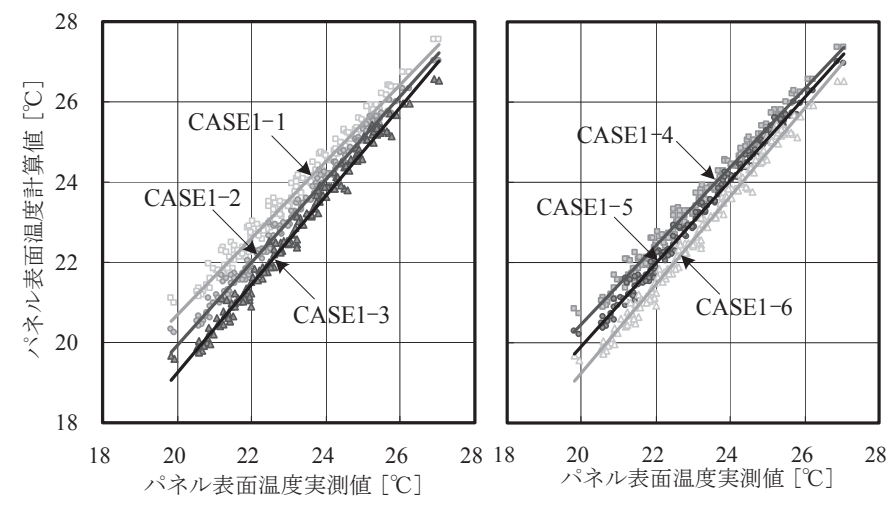

図 11 冷房時放射パネル表面温度計算值と実測值

と流量, 熱伝達率, パネル周囲環境温度, および放射パネルのフィ ン効率から放射パネルの熱量を推定することができる。

\section{5. 放射パネルのフィン効率の推定}

対象とした放射パネルのフィン効率を推定するため, 熱交換式に おいて, フィン効率, 接触抵抗を仮定し, 送水往温度, 送水流量, 空 気温度, PRT 実測值から式(1), 式(33)より, 放射パネル熱量とパネ ル表面温度を算出し, 実測值と比較する。

表 6 に計算条件を示す。熱交換式において各表面熱伝達率は, 実 測により得られた值を用い, 表 7 に示寸接触抵抗とフィン効率を与 えて算出する。

図 10, 11 に冷房時における放射パネル熱量, 室内側パネル表面温 度の計算值と実測值を示す。フィン効率が高くなるにつれて, 放射 パネル表面温度は送水温度に近い值となり，放射パネル熱量は多く なる。この傾向は送水温度と環境温度の差が大きくなるにつれて顕 著になる。また, 接触抵抗が大きくなると放射パネル熱量は少なく なり，CASE1-2 と CASE1-5 の放射パネル熱量と表面温度計算值は実測 值と概ね一致する傾向がみられる。

図 12, 13 に暖房時における放射パネル熱量, 室内側パネル表面温 度の計算值と実測值を示す。冷房時と同様に放射パネル熱量は, フィン効率が高くなるにつれて多くなるが，接触抵抗が大きくなる と少なくなる。CASE2-2 と CASE2-5 の放射パネル熱量と表面温度計算 值は実測值と概放一致する傾向がみられる。

一方で, フィン効率 $\eta$ は式(36) で表せる。

$\eta=\frac{t_{p}-t e}{t_{p o f}-t e}$

赤外線サーモグラフィによる放射パネル表面の熱画像より，放射
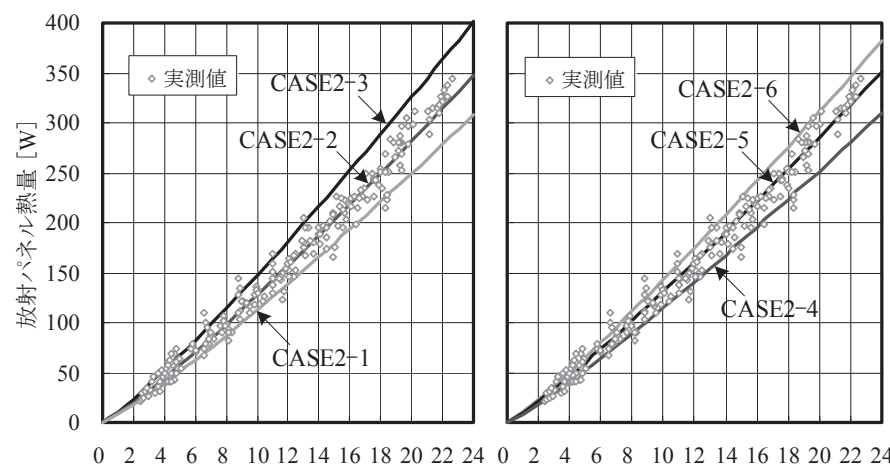

$\begin{array}{llllllllllllll}8 & 0 & 18 & 18 & 22 & 24\end{array}$ 送水温度と環境温度の差 $[\mathrm{K}]$ 送水温度と環境温度の差 $[\mathrm{K}]$

図 12 暖房時放射パネル熱量計算值と実測值

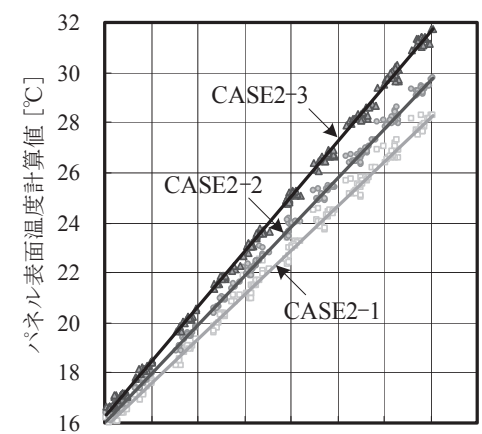

$\begin{array}{llllllllll}16 & 18 & 20 & 22 & 24 & 26 & 28 & 30 & 32 & 16\end{array}$ パネル表面温度実測值 $\left[{ }^{\circ} \mathrm{C}\right]$

パネル表面温度実測值 $\left[{ }^{\circ} \mathrm{C}\right]$ 図 13 暖房時放射パネル表面温度計算值と実測值

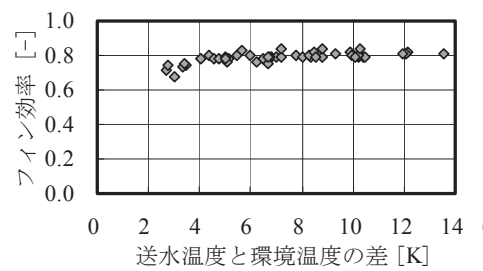

(a) 冷房

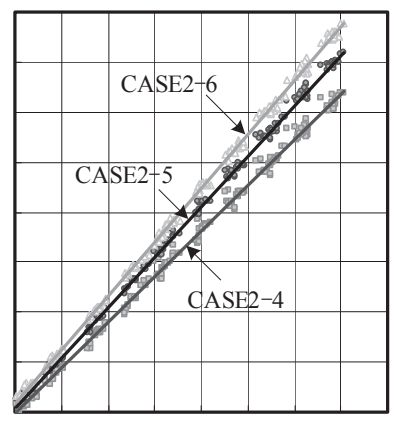

$\begin{array}{llllllll}8 & 20 & 22 & 24 & 26 & 28 & 30 & 32\end{array}$

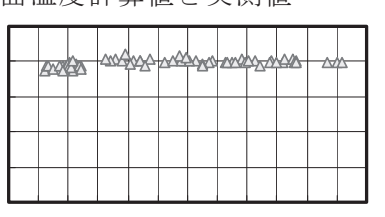

$\begin{array}{lllllllllll}0 & 2 & 4 & 6 & 8 & 1012141618202224\end{array}$ 送水温度と環境温度の差 $[\mathrm{K}]$

(b) 暖房
図 14 熱画像解析によるフィン効率

パネル全体の平均表面温度 $t_{p}$ と根元温度 $t_{p o f}$ を求め, 式(36)からフィ ン効率を算出することを試みる。図 14 に熱画像から算出したフィン 効率を示す。フィン効率は冷暖房時ともに概初約 0.79 となる。した がって, 熱交換式において対象放射パネルは接触抵抗を $0.01 \mathrm{~m}^{2} \mathrm{~K} / \mathrm{W}$, フィン効率を 0.79 とすると, 放射パネル熱量と表面温度を精度良く 予測できると考えられる。

\section{6、放射パネル熱伝達性能に関する要因の影響評価}

熱交換式において，配管の熱伝導率，フィン効率，送水条件が，放

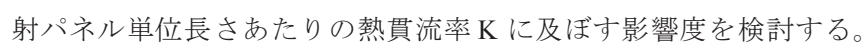
なお，放射パネルの環境温度は室内側，天井内側ともに，冷房時は $28^{\circ} \mathrm{C}$, 暖房時は $20^{\circ} \mathrm{C}$ と, 放射パネル条件は, 検討項目以外は表 6 , 及び表 7 の CASE1-5, CASE2-5 に示寸条件で固定する。

図 15 に配管熱伝導率と熱貫流率の関係を示す。熱貫流率は, 配管 熱伝導率により $1 \sim 2 \mathrm{~W} / \mathrm{mK}$ となり，配管熱伝導率の影響を大きく受 けるが，配管熱伝導率が $10 \mathrm{~W} / \mathrm{mK}$ 以上となると，ほぼ一定となる。

図 16 にフィン効率と熱貫流率の関係を示す。フィン効率が大きく なるにつれて, 熱貫流率はほぼ一定の割合で大きくなり, フィン効 率 $0.5 \sim 1.0$ の範囲では, 熱貫流率は約 $1.1 \sim 1.7 \mathrm{~W} / \mathrm{mK}$ で, フィン効率 0.1 の変化に対し，熱貫流率は約 $10 \%$ 変化する。 
図 17 に送水条件と熱貫流率の関係を示す。冷暖房時ともに送水往 温度と環境温度の差が大きくなるにつれて熱貫流率が大きくなる。 これはパネル表面温度と環境温度の差が大きくなり, 対流熱伝達率 が増加するためと考えられる。また送水流速が $0.5 \mathrm{~m} / \mathrm{s}$ 以下では熱貫 流率が僅かに変化するが， $0.5 \mathrm{~m} / \mathrm{s}$ 以上ではほぼ一定となる。

\section{7. 放射パネル直列接続時における熱量の検討}

対象とした放射パネルを直列接続した場合における熱量を熱交換 式を用いて算出する。図 18 に計算条件を示す。放射パネル 7 枚を直 列に接続し, 各放射パネルの環境温度を室内側, 天井内側ともに, 冷房時は $28^{\circ} \mathrm{C}$, 暖房時は $20^{\circ} \mathrm{C}$ して, 送水条件を変化させて, 各放 射パネル熱量を算出する。

図 19 に送水往温度と環境温度の差が $12 \mathrm{~K}$ の場合における各放射パ ネルの設置面積あたりの熱量を示す。各放射パネルの熱量は配管内 の流速が小さくなるにつれて, 下流側の放射パネルの熱量が少なく なる。これは, 配管内の流速, 寸なわち送水流量が少なくなるにつ れて, 各放射パネル出入口の温度差が大きくなり，下流側の放射パ ネルへの送水温度と環境温度の差が小さくなるためである。これら の結果をもとに 7 枚直列接続時の設置面積あたり放射パネル平均熱 量を算出すると, 図 20 のような熱量特性が得られる。平均熱量は低 流速時において流速の影響が大きいが，流速が速くなるにつれて流 速による影響は小さくなり, 送水往温度による影響が大きくなるこ とが分かる。

\section{8.まとめ}

スリットを有し，フィン付き配管独立構造である天井放射パネル の熱性能について，実験により冷暖房時における表面熱伝達率を求
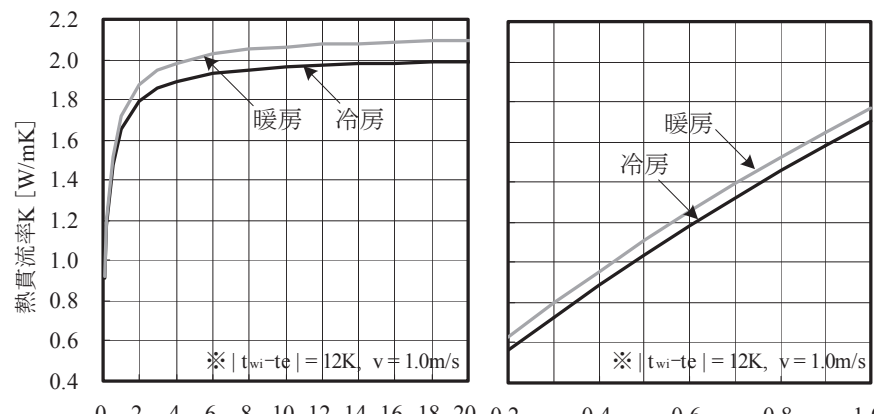
配管熱伝導率 $[\mathrm{W} / \mathrm{mK}]$

フイン効率 [-]

図 15 配管熱伝導率と熱貫流率

図 16 フィン効率と熱貫流率

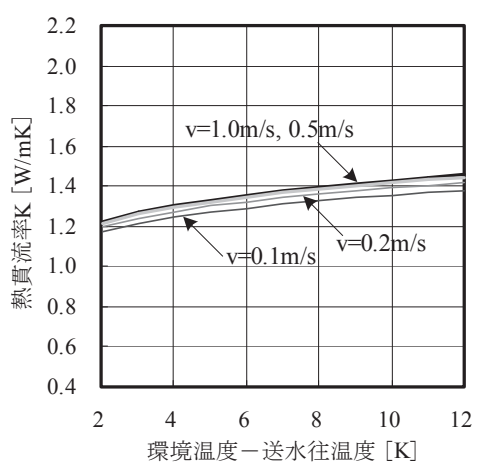

(a) 冷房時

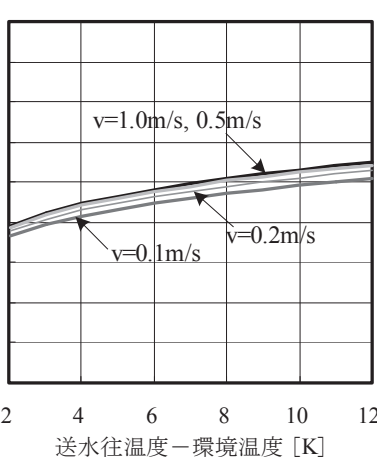

(b) 暖房時
図 17 送水温度, 流速と熱貫流率
め，放射パネルの熱交換式を導いて熱量特性を検討した。得られた 知見は以下の通りである。

1) 実験より求めた放射パネル表面における放射熱伝達率は，冷房時 が $5.4 \mathrm{~W} / \mathrm{m}^{2} \mathrm{~K}$, 暖房時が $5.3 \mathrm{~W} / \mathrm{m}^{2} \mathrm{~K}$, 室内側対流熱伝達率は，冷房時が $2.3\left|\mathrm{t}_{\mathrm{p}}-\mathrm{ta}_{\mathrm{a}}\right|{ }^{0.43} \mathrm{~W} / \mathrm{m}^{2} \mathrm{~K}$ ，暖房時が $2.2\left|\mathrm{t}_{\mathrm{p}}-\mathrm{ta}_{\mathrm{a}}\right|{ }^{0.25} \mathrm{~W} / \mathrm{m}^{2} \mathrm{~K}$ ，天井内側対流熱伝 達率は, 冷房時が $2.9\left|\mathrm{t}_{\mathrm{p}}-\mathrm{ta}_{\mathrm{a}}\right|^{0.16} \mathrm{~W} / \mathrm{m}^{2} \mathrm{~K}$, 暖房時が $2.9\left|\mathrm{t}_{\mathrm{p}}-\mathrm{t}_{\mathrm{a}}\right|{ }^{0.39} \mathrm{~W} / \mathrm{m}^{2} \mathrm{~K}$ で あった。

2) 天井放射パネルの熱量をフィン効率を用いて，送水条件と，パネ ル周囲の空気温度とPRT の影響を考慮した環境温度から評価できる 熱交換式を導いた。

3) 熱交換式による放射パネル熱量と表面温度を実測值を比較した結 果，対象とした放射パネルは，接触抵抗を $0.01 \mathrm{~m}^{2} \mathrm{~K} / \mathrm{W}$ ，フィン効率を 0.79 とした場合に実測值と概ね一致した。

4) 熱交換式から配管熱伝導率，フィン効率，送水温度と流量につい て，放射パネル単位長さあたりの熱貫流率に及ぼす影響を解析した 結果，配管の熱伝導率による影響が特に大きく，送水温度や流量に よる影響は比較的小さいことが分かった。

5) 直列接続した場合における放射パネルの熱量を熱交換式で試算し

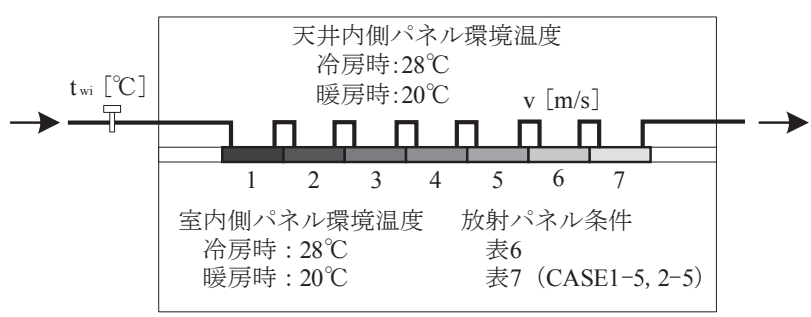

図 18 直列接続時の放射パネル熱量計算条件

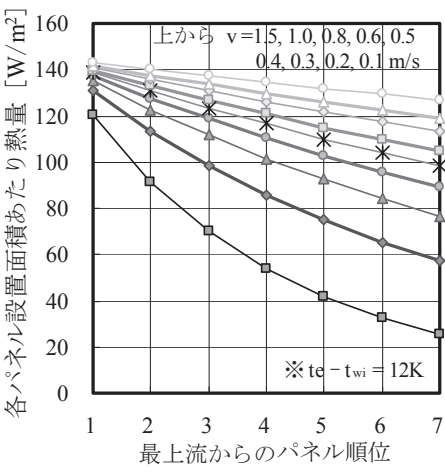

(a) 冷房時

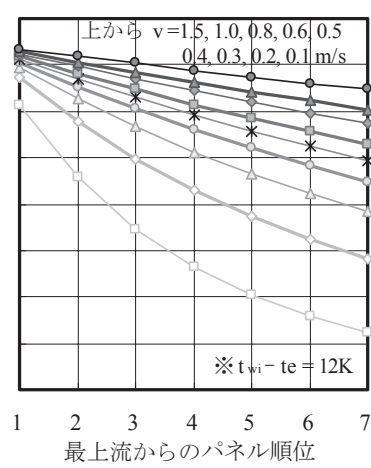

(b) 暖房時
図 19 各放射パネル熱量

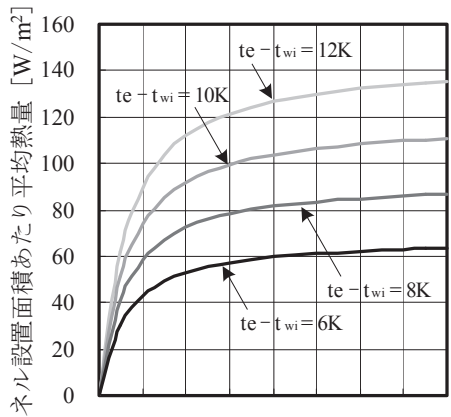

$\begin{array}{llllllllllllllllll}0.0 & 0.2 & 0.4 & 0.6 & 0.8 & 1.0 & 1.2 & 1.4 & 1.6 & 0.0 & 0.2 & 0.4 & 0.6 & 0.8 & 1.0 & 1.2 & 1.4 & 1.6\end{array}$ パネル管内流速 $[\mathrm{m} / \mathrm{s}$ ]

(a) 冷房時

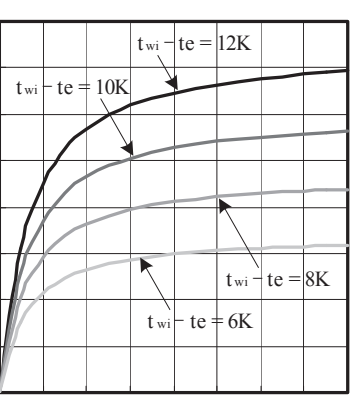

パネル管内流速 $[\mathrm{m} / \mathrm{s}$ ]

(b) 暖房時
図 207 枚直列接続時における放射パネル熱量 
た結果, 放射パネルの平均熱量は, 流速が速くなるにつれて流速に よる影響が小さくなり，送水往温度による影響が大きくなることが 分かった。

提案した熱交換式は，送水条件や直列接続枚数による放射パネル の熱量, および放射パネル表面温度による室内放射環境評価などの 検討を行う上で利用でき, 室内空気温度と周囲表面温度を区別し, 天井放射空調システムの特徵である放射環境を考慮した設計手法を 確立する上で有用であることを示唆した。配管とパネルを接続する 型式の放射パネルは，パネルや配管の形状や材質，フィン効率と配 管パネル間の接触抵抗が分かれば，熱交換式における放射パネル固 有の熱貫流率が分かり，熱量特性が推定可能と考えられる。フィン 効率と接触抵抗は, 熱交換式による放射パネルの熱量と表面温度を 実測值と比較することにより簡易的に求めることが可能である。

今後は熱交換式の簡易化を検討し，様々な熱負荷条件下で適用し， 天井放射パネルの熱量特性とスリットがあることによる室内側への 放熱量移動効果や，形成される室内温熱環境を解析する予定である。

\section{参考文献}

1) 瀬沼央, 武田仁 : 長期実測による井戸水利用天井放射冷房システムの評 価，日本建築学会環境系論文集，No.623，pp.31-38，2008.1

2) 瀬沼央, 武田仁：長期実測による太陽熱利用天井放射暖房システムの評 価, 日本建築学会環境系論文集, No.627, pp.599-606, 2008.5

3) 迫博司, 高橋幹雄, 塩谷正樹, 桑原亮一 : 放射環境を考慮した自然エネル ギー利用のオフィス空調システムの構築, 日本建築学会技術報告集,

No.34, pp.1041-1044, 2010.10

4) 桑原亮一, 塩谷正樹, 大倉俊雄, 大谷光幸 : ゼロエネルギー・ビルを目指 した建築設備技術に関する研究 その 1 システム概要と放射空調システ 厶の設計計画, 日本建築学会大会学術講演梗概集, 環境工学 II, pp.1309-1310, 2010.9

5) 中村駿介, 佐々木邦治, 小野景子, 三木光範, 高盈, 鄭新源, 宗方淳, 川瀬貴晴 : LED 知的照明システム・輻射空調システムを導入した「低炭素 型実証オフィス」の運用実績 その 1 施設概要および輻射空調システム 性能評価, 日本建築学会大会学術講演梗概集, 環境工学 II, pp.1071-1072, 2010.9
6) 石野久爾 : 輻射冷暖房方式の設計用熱負荷計算法の提案 第 2 報 定常計 算法と計算適用例, 日本建築学会大会学術講演梗概集, 環境工学 II, pp.161-162, 1997.9

7)ASHRAE: ASHRAE Handbook, HVAC Systems and Equipment(SI), pp.6.2-6.6, 2008

8) 瀬沼央, 武田仁 : 輻射冷暖房パネルの熱特性実験と数值解析, 日本建築学 会計画系論文集, No.500, pp.15-21，1997.10

9) 系井川高穂, 羽山広文, 絵内正道, 山岸浩, 山北聡, 菊田弘輝 : 病室を対 象とした天井放射冷房の性能評価に関する実験的研究一負荷の日変動の再 現実験一, 空気調和・衛生工学会大会学術講演論文集, pp.1153-1156, 2006.9

10) 伊藤清, 川島実, 荒井義人, 鈴木道哉, 村上宏次, 野部達夫 : 天井放射 空調システムの熱的性能評価実験及び被験者による温熱環境評価実験, 日本建築学会技術報告集，No.38，pp.243-248，2012.2

11) 川島実, 郷正明, 荒井義人, 鈴木道哉, 村上宏次, 伊藤清, 野部達夫 : 放射空調システムの検討 その 4 対流促進型放射パネルを設けた天井放 射空調システム構成と熱的性能評価実験内容, 日本建築学会大会学術講演 梗概集，環境工学 II , pp.1287-1288，2011.8

12) 伊藤清, 郷正明, 川島実, 荒井義人, 鈴木道哉, 村上宏次, 野部達夫 : 放射空調システムの検討 その 5 対流促進型放射パネルを設けた天井放 射空調システムの熱的性能評価実験結果, 日本建築学会大会学術講演 梗概集，環境工学 II , pp.1289-1290, 2011.8

13) 今川裕二, 中村仁秋, 岸本卓也, 木虎久隆, 岡本茂, 岡建雄 : 天井放射 空調システムに関する研究 第 1 報 放射パネルの単体性能評価, 日本建 築学会大会学術講演梗概集, 環境工学 II , pp.1281-1282, 2011.8

14) 岸本卓也, 木虎久隆, 岡本茂, 今川裕二, 中村仁秋, 岡建雄 : 天井放射 空調システムに関する研究 第 2 報 実験室の概要と空調方式比較，日本 建築学会大会学術講演梗概集, 環境工学 II, pp.1283-1284, 2011.8

15) 岡本茂, 三浦光城, 山口弘雅, 尾本和夫, 高岡昌史, 岡建雄 : 天井放射 冷暖房用パネルの性能予測計算方法と実験值の比較, 日本建築学会環境系 論文集，No.624，pp.221-227，2008.2

16) 三村涉, 羽山広文, 菊田弘輝, 山岸浩 : 天井放射パネルの熱伝達特性の 検討，空気調和・衛生工学会大会学術講演論文集，pp.1131-1134，2010.9 17) 空気調和・衛生工学会 : 空気調和衛生工学便覧第 14 版 1 基礎編, pp. $88-89,2010$

18）日本機械学会：伝熱工学資料改訂第 4 版, p. 202, 1986

19) 空気調和・衛生工学会 : 空気調和衛生工学便覧第 14 版 1 基礎編, p. 77,2010 